\title{
Diet, provisioning and productivity responses of marine predators to differences in availability of Antarctic krill
}

\author{
J. P. Croxall*, K. Reid, P. A. Prince \\ British Antarctic Survey, Natural Environment Research Council, High Cross, Madingley Road, Cambridge CB3 0ET, \\ United Kingdom
}

\begin{abstract}
Knowledge of relationships between prey availability and predator performance is the key to using predators as indicators of the state of marine systems and to assessing potential consequences of competition between natural predators and man for common resources. Fluctuations in the abundance of Antarctic krill are believed to have a substantial influence on the reproductive performance of krill-dependent top predator species in the Southern Ocean; few quantifications of such interactions exist. At South Georgia, for 2 years in which acoustic surveys revealed a major difference in krill abundance, we compared diet, provisioning of offspring and breeding success in 4 main predator species (2 penguins, 2 albatrosses, with supporting data from Antarctic fur seal) whose dependence on krill typically ranges from 20 to $90 \%$. The 4 -fold difference in krill biomass between 1986 (ca $30 \mathrm{~g} \mathrm{~m}^{-2}$ )

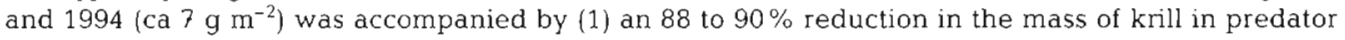
diets (and some increase in the fish component), (2) greater prey diversity for most species, (3) reduced diet overlap between species and (4) a switch from krill to amphipods in macaroni penguin but no major dietary change in other species. Rates of provisioning of offspring decreased by $90 \%$ in gentoo penguin and 40 to $50 \%$ in the other 3 species; this was due to reduced meal size in penguins (by $90 \%$ in gentoo and $50 \%$ in macaroni) and to doubling of foraging trip duration in albatrosses. Breeding success was reduced by $50 \%$ in grey-headed albatross (the species least dependent on krill), by $90 \%$ in black-browed albatross and gentoo penguin (only 3 to $4 \%$ of eggs producing fledged chicks) but by only $10 \%$ in macaroni penguin, presumably reflecting its ability to switch to small prey unprofitable for the other species. However, all species (except for black-browed albatross), particularly macaroni penguin, produced fledglings significantly lighter than usual, probably affecting their subsequent survival. Some effects on adult survival could also be inferred. Our results show a coherent, though complex, pattern of within and between species similarities and differences. These mainly reflect the degree of dependence on krill, the feasibility of taking alternative prey and constraints on trip duration and/or meal size imposed by foraging adaptations (especially relating to travel speeds and diving abilities, whereby flightless divers and pelagic foragers differ markedly). The generality of these principles are explored through comparison with other studies, particularly of Shetland seabirds.
\end{abstract}

KEY WORDS: Predator performance P Prey availability $\cdot$ Antarctic krill - Albatrosses · Penguins · Fur seals

\section{INTRODUCTION}

In marine systems many top predators specialise on particular classes or species of prey. Their breeding populations and especially productivity (breeding suc-

\footnotetext{
•E-mail: j.croxall@bas.ac.uk
}

cess) are, therefore, potentially vulnerable to fluctuations (whether natural or anthropogenic) in availability of their main prey. Such circumstances are the basis for many long term studies seeking to use variation in predator populations and/or breeding performance as indicators of variations in prey abundance and/or availability (Croxall \& Prince 1979, Cairns 1987, Croxall et al. 1988, Montevecchi et al. 1988, Monaghan et 
al. 1989, Montevecchi \& Berruti 1991, Furness \& Greenwood 1993, Hamer et al. 1993, Ainley et al. 1995. Monaghan 1996). However, in very few studies are estimates of prey abundance, independent of those derived from predator diet or breeding success, available (Anderson et al. 1982, Burger \& Piatt 1990, Uttley et al. 1994). Furthermore, the ability even of specialist predators to switch to alternative prey is poorly understood.

Antarctic krill Euphausia superba is a key food resource for many species of top predators in the Southern Ocean (Croxall \& Prince 1980, Croxall 1984, Reid \& Arnould 1996, Croxall et al. 1997). This is particularly the case in the austral summer the main predator breeding season) and in the Antarctic and sub-Antarctic (especially South Georgia) regions of the South Atlantic sector. However, there are clear indications that, from time-to-time, the availability of krill to top predators, either locally or regionally, is substantially reduced (Croxall et al. 1988, Priddle et al. 1988, Boyd et al. 1994, Lunn et al. 1994). Much of the evidence for this is relatively circumstantial, usually being derived retrospectively from reduced reproductive performance of one or more of the predators of krill. Very seldom have concurrent quantitative data been available on predator diets and on the abundance of krill at appropriate scales. Indeed, in only 2 years in the last decades, 1986 and 1994, has the detailed annual monitoring of breeding population size and performance of a range of key species of top predators at Bird Island, South Georgia (Croxall et al. 1988, Prince et al. 1994, Boyd et al. 1995, Croxall \& Rothery 1995), been accompanied by quantitative research into their diets in conjunction with simultaneous assessment of krill abundance and availability in surrounding waters (Brierley \& Watkins 1996, C. Goss unpubl. data).

In this paper we compare data on predator diet. breeding population size and productivity at South Georgia in the austral summers of 1985/86 and $1993 / 94$ in the light of the results of acoustic echo-integration surveys which indicated that around South Georgia in 1993/94 krill was very scarce and patchy in abundance and distribution (Brierley et al. 1997) and several-fold less abundant than in some previous years (including 1986) when comparable surveys had taken place.

In particular we ask (1) How well do predator diets reflect the potential differences in krill availability in 1986 and 1994? (2) Are any predator species able to compensate for low availability of krill by switching to other prey? and (3) How do differences in predator diet between years relate to breeding success in these years?

In addition to their intrinsic interest, the answers to these questions also make potentially important contri- butions to the evaluation of results from long-term monitoring studies of breeding population size and success in top predators in general and in the Antarctic in particular. The difficulties and costs of conducting annual surveys of krill distribution and abundance at appropriate spatial scales make the use of indices of predator performance to assess krill abundance particularly attractive. However this requires that the nature of interactions between predator and prey coften referred to as functional relationships - see Butterworth \& Thompson 1995) is adequately understood.

\section{METHODS}

Study species. For critical comparisons between 1986 and 1994 we focused on 4 species: 2 aerial pelagic foragers (grey-headed and black-browed albatrosses Diomedea chrysostoma and D. melanophris) and 2 flightless diving foragers (gentoo and macaroni penguins Pygoscelis papua and Eudyptes chrysolophus). In both years we have comprehensive quantitative data on composition of the diet, on the size of krill taken and on breeding population size and breeding success; similar data are also available in some other years. In addition, for Antarctic fur seals Arctocephalus gazella we have data on composition of the diet (in terms of frequency of occurrence), on the size of krill taken and the population size and breeding success in both years For Antarctic prions Pachyptila desolata we have data on composition of the diet in both years.

Diet. Food samples were collected at weekly intervals during February of both 1986 and 1994 from adults of all species returning to feed offspring at Bird Island, South Georgia. Samples from penguins were collected by stomach lavage (Wilson 1984) using the method of CCAMLR (1995), whereas samples from albatrosses were collected by intercepting meals immediately prior to the chick being fed (see Prince 1980b). Antarctic prion samples were collected as spontaneous regurgitations from adults mist netted above breeding burrows (see Prince 1980a). Samples from Antarctic fur seal were obtained by lavaging lactating females immediately after they arrived ashore in 1986 and by collecting faeces (scats) in 1994 (see Reid \& Arnould 1996)

All samples were weighed, then separated into 3 main prey categories (crustacean, cephalopod, fish); the mass of each category, along with any unidentified material was recorded. All cephalopod lower mandibles and fish otoliths were identified and measured following Clarke (1986), Hecht (1987), Williams \& McEldowney (1990) and Reid (1996) and by reference to collections and unpublished data at the British Antarctic Survey (BAS) (see e.g. Reid et al. 1996a). 
Crustaceans were identified in association with appropriate BAS specialists using extensive reference collections from the South Georgia area. The sex and maturity stages of krill were assessed using the method of Makarov \& Denys (1981) following the nomenclature of Hill (1990). The total length (AT) of krill was measured using the removed carapace length (RCL) and the appropriate regression relationship for each maturity/sex stage as given in Hill (1990).

The occurrence of each prey taxon is represented by its frequency of occurrence (the total number of samples in which the taxon was recorded/total number of samples) and proportionate mass (the total mass of the taxon/mass of all samples). Only frequency of occurrence data are available from the fur seal samples. The mass of euphausiids and the amphipod Themisto gaudichaudii was obtained by direct weighing; the mass of each cephalopod and fish taxon was estimated using the contribution of that taxon to the reconstructed mass of the prey group. Diet diversity was quantified using Shannon-Weaver (1949) indices, and dietary overlap indices were calculated by a modified version of Morisita's equation adapted from Diamond (1983); the overlap index $C$ is given by :

$$
C=\frac{2 \sum_{i=1}^{s} x i y i}{\sum_{i=1}^{s} x i 2+\sum_{i=1}^{s} y i 2}
$$

where $s$ is the number of categories represented in the diets of species $x$ and $y$.

Population size and breeding success. For albatrosses and penguins the number of pairs laying eggs and the proportion of these pairs successfully rearing chicks has been recorded at the same selected study colonies on Bird Island in each year since 1976 (see e.g Croxall et al. 1988, Prince et al. 1994). For Antarctic fur seals the number of females giving birth and the survival of pups to $6-8 \mathrm{wk}$ of age has been recorded annually at the same study site on Bird Island since 1981 (see Croxall et al. 1988, Lunn et al. 1994, Boyd et al. 1995).

Prey availability. Acoustic estimates of krill abundance were conducted using standard techniques; cruise and survey details are given in Brierley et al. (1998); most details, especially relating to survey design, area, equipment and methodology is also provided in Hunt et al. (1992) and Brierley \& Watkins (1996).

\section{RESULTS \\ Diet}

Full details of the composition of the diets of albatrosses and penguins in 1986 can be found in Croxall et al. (1997 Appendix 1 therein); equivalent details for 1994 are given here in Appendix 1. Overall diet composition in the $2 \mathrm{yr}$ is summarised in Table 1 and compared with the average diet for all other years for which we have data. In broad terms, these data indicate that the 4 species selected for the main study can be placed in a graded sequence of increasing dependence on krill, at least with respect to data for 1986 and 1976 to 1995 . Thus grey-headed albatrosses are least

Table 1. Composition (percentage by mass) of the main prey groups in the diet of predators during the breeding seasons of 1986 and 1994 at South Georgia, with comparison with data from other years. The chi-squared statistic and the level of significance ( " p p 0.01) of differences from equivalent proportional composition of the diet in both 1986 and 1994 are also shown

\begin{tabular}{|c|c|c|c|c|c|c|c|}
\hline Species & Year & $\%$ Fish & $\%$ cephalopod & $\%$ krill & $\%$ amphipod & $x^{2}$ & $\mathrm{p}$ \\
\hline Grey-headed albatross & $\begin{array}{c}1986 \\
1994 \\
\text { Other }\end{array}$ & $\begin{array}{l}13.6 \\
60.8 \\
26.8\end{array}$ & $\begin{array}{l}70.5 \\
37.7 \\
54.1\end{array}$ & $\begin{array}{r}15.9 \\
1.5 \\
18.0\end{array}$ & $\begin{array}{l}0.0 \\
0.0 \\
0.0\end{array}$ & 5483.9 & . \\
\hline Black-browed albatross & $\begin{array}{c}1986 \\
1994 \\
\text { Other }\end{array}$ & $\begin{array}{l}29.5 \\
72.4 \\
36.1\end{array}$ & $\begin{array}{l}31.1 \\
22.9 \\
26.8\end{array}$ & $\begin{array}{r}39.4 \\
4.7 \\
34.3\end{array}$ & $\begin{array}{l}0.0 \\
0.0 \\
0.0\end{array}$ & 4382.6 & * \\
\hline Gentoo penguin & $\begin{array}{c}1986 \\
1994 \\
\text { Other }\end{array}$ & $\begin{array}{l}31.0 \\
85.9 \\
36.3\end{array}$ & $\begin{array}{l}0.0 \\
1.2 \\
0.0\end{array}$ & $\begin{array}{r}69.0 \\
9.0 \\
63.2\end{array}$ & $\begin{array}{l}0.0 \\
3.6 \\
3.0\end{array}$ & 4499.7 & . \\
\hline Macaroni penguin & $\begin{array}{c}1986 \\
1994 \\
\text { Otherc }\end{array}$ & $\begin{array}{r}2.3 \\
15.0 \\
4.0\end{array}$ & $\begin{array}{l}0.0 \\
1.0 \\
1.3\end{array}$ & $\begin{array}{l}95.0 \\
13.1 \\
89.8\end{array}$ & $\begin{array}{c}2.7 \\
67.3 \\
10.5\end{array}$ & 19527.9 & * \\
\hline \multicolumn{8}{|c|}{$\begin{array}{l}\text { 'Mean from } 3 \text { other years between } 1976 \text { and } 1980 \\
{ }^{b} \text { Mean from } 11 \text { other years between } 1977 \text { and } 1995 \\
\text { 'Mean from } 9 \text { other years between } 1977 \text { and } 1995\end{array}$} \\
\hline
\end{tabular}


reliant on krill, whether in $1986(16 \%)$ or on average $(18 \%)$, followed by black-browed albatrosses (39 and $34 \%$ ), gentoo penguins (69 and 63\%) and macaroni penguins (95 and 90\%). Alternatively, grey-headed albatrosses can be regarded as mainly targeting squid and fish, black-browed albatrosses as taking all 3 prey groups in roughly similar proportions, gentoo penguins as eating mainly krill but with a substantial portion of fish, and macaroni penguins as mainly taking krill.

For all species, however, there were significant differences in diet between 1986 and 1994 (Table 1). The main difference was the substantially lower contribution of krill to the diet in 1994 , with values only $9 \%$ (grey-headed albatross) to $14 \%$ (macaroni penguin) of those in 1986 (i.e. about a 90\% reduction in importance). All species showed an increase in the contribution of fish to their diet in 1994, with values between $15 \%$ (macaroni penguin) and $41 \%$ (black-browed albatross) higher than in 1986 . The proportion of squid in albatross diet was lower in 1994 by $26 \%$ (blackbrowed albatross) to $47 \%$ (grey-headed albatross) but essentially unchanged in penguins, for which squid is little more than a trace component of the diet. Macaroni penguin diet was unusual in 1994 in that it was largely comprised of amphipods.

\section{Crustaceans}

In addition to the differences in the proportions of krill taken by albatrosses and penguins in 1986 and 1994, the nature of these krill was different between the 2 years. Krill were larger in 1986, with significant differences in the length-frequency distribution of krill taken by macaroni (Kolmogorov-Smirnov $D=0.92$, $\mathrm{p}<$
0.001 ) and gentoo penguins (Kolmogorov-Smirnov $D=$ $0.90, p<0.01$ ) (Fig. 1) and in the maturity/sex stage composition of krill taken by macaroni $\left(\chi_{6}^{2}=557.1, \mathrm{p}<\right.$ $0.01)$ and gentoo penguins $\left(\chi_{6}^{2}=62.9, p<0.001\right)$ (Fig. 2) Sexually active female krill were rare or absent in 1994 but were the commonest category in 1986; conversely, juvenile, sub-adult female and sexually non-active female krill dominated the 1994 samples.

There was insufficient krill in samples from albatrosses in 1994 for comparison between years but the size and status of krill in their diets in 1986 was very similar indeed to those of the penguins (Reid et al. 1996b). Krill occurred in all samples from Antarctic fur seals in 1986 and in $88 \%$ of samples in 1994. The size of krill taken by Antarctic fur seals was significantly different between years (Kolmogorov-Smirnov $D=$ $0.71, p<0.001$ ) and did not differ significantly from the krill taken by gentoo penguins in either year (Fig. 2).

\section{Fish}

Fish formed a much larger part of the diet of each species in 1994 than in 1986 and was the dominant prey type in the diet of 3 of the 4 seabird predators (not macaroni penguin) in 1994 (Table 1). There were also substantial differences in the composition of the fish diet between the 2 years (Fig. 3). Thus only 3 fish species (the lamprey Geotria australis in grey-headed albatrosses, the icefish Champsocephalus gunnari in gentoo penguins and the myctophid Krefftichthys anderssoni in macaroni penguins) occurred in more than 1 sample from the same seabird species in both years.

In the diet of both species of albatross the dominant fish species in 1986 was either absent (the nototheniid Patagonotothen guntheri in black-browed albatrosses)
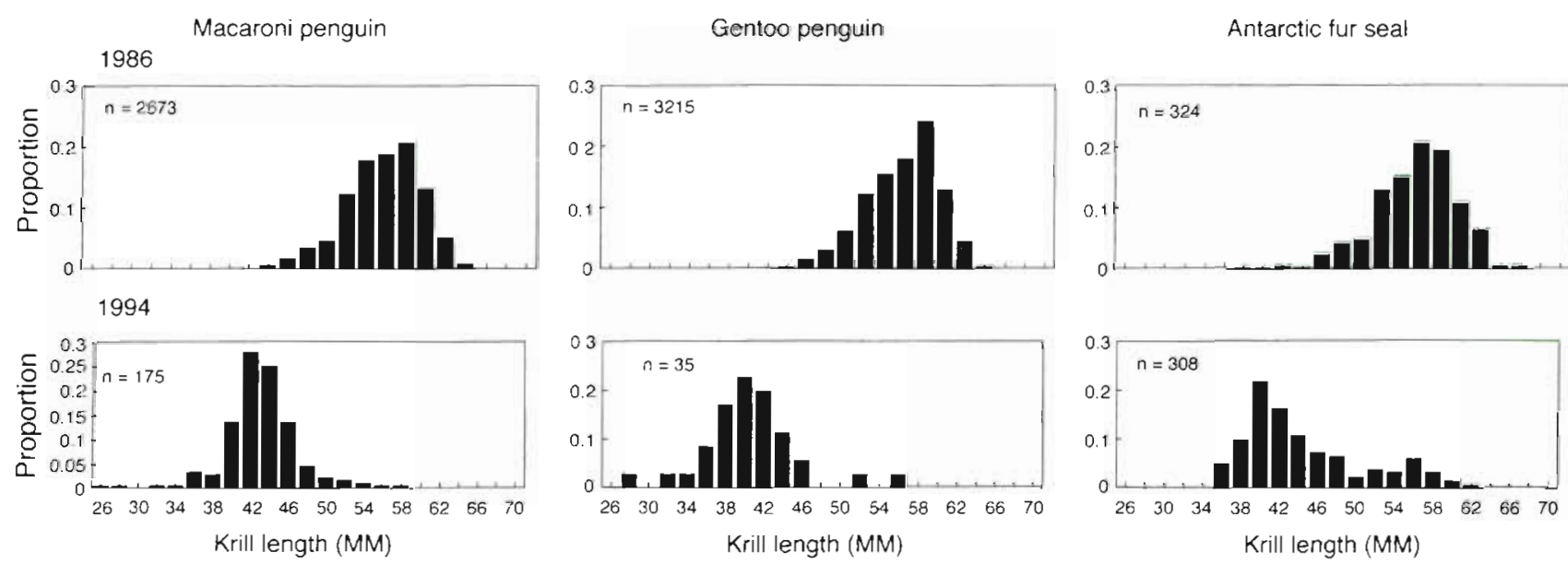

Fig. 1. Length-frequency distribution of Antarctic krill Euphausia superba in the diet of macaroni penguin, gentoo penguin and Antarctic fur seal during the breeding seasons of 1986 and 1994 

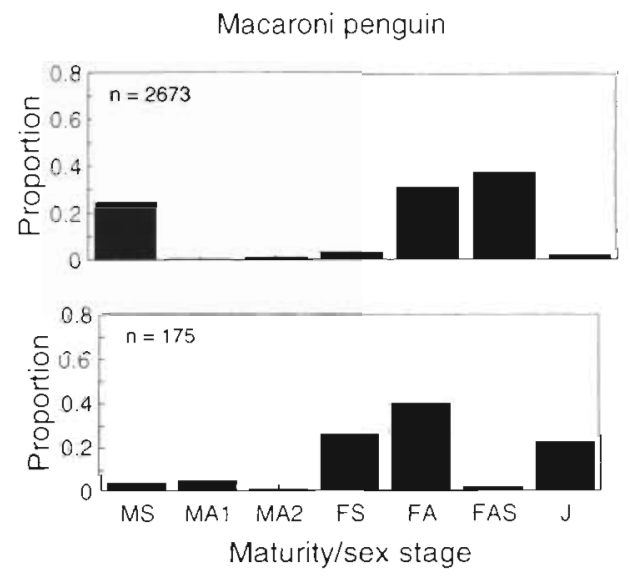

Gentoo penguin
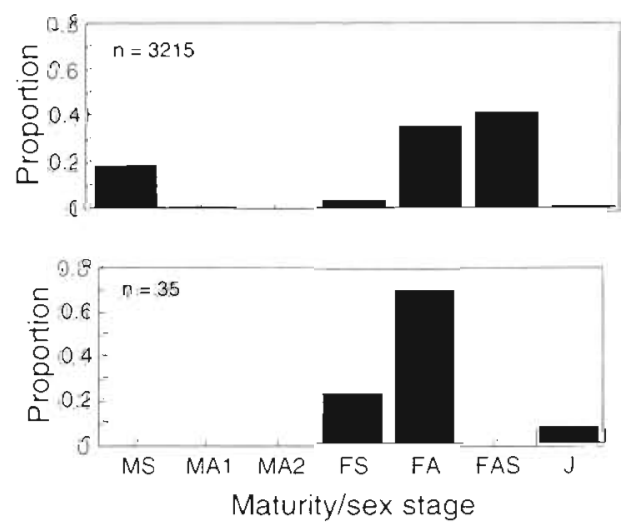

Fig. 2. Maturity/sex stage composition of Antarctic krill Euphausia superba in the diets of macaroni and gentoo penguins during the breeding seasons of 1986 and 1994. Maturity/sex codes follow the methods of Makarov \& Denys (1981) using the nomenclature of Hill (1990)

or formed a much smaller part of the diet (Geotria australis in grey-headed albatrosses) in 1994. None of the dominant fish species in 1994 -the icefish Pseudochaenichthys georgianus (grey-headed albatross), the paralepid Magnisudis prionosa (both species) and Champsocephalus gunnari (black-browed albatross) was present in the diet in 1986 .

The most important fish species in the diet of gentoo penguins, Champsocephalus gunnari, formed $27 \%$ by mass of the diet in 1986 and $81 \%$ in 1994, when it was the single most important prey item. A combination of icefish and myctophids formed a small proportion of the diet of macaroni penguins in both years.

There were no fish remains in samples from Antarctic fur seals in 1986; however, $78 \%$ of scats collected in 1994 contained fish. This was considerably more than in the 3 previous summers (range 10 to $67 \%$ ); the myctophid Protomyctophum choriodon was the most numerous fish species in all years, including 1994 (Reid \& Arnould 1996).

\section{Cephalopods}

Of all main prey types, the squid element of the diet differed least between 1986 and 1994, with the ommastrephid Martialia hyadesi being the dominant cephalopod species in the diet of both grey-headed and black-browed albatrosses in both years, although forming a smaller proportion of the cephalopod portion of the diet in the latter species. The onychoteuthid Kondakovia longimana and the cranchid Galiteuthis glacialis were also common in the diets of both albatross species; together these 3 species contributed 86 to $100 \%$ and 88 to $94 \%$ of the cephalopod diet of greyheaded and black-browed albatrosses, respectively.
Cephalopods formed a small part of the diet of gentoo penguins in 1986 and of gentoo and macaroni penguins in 1994. It was not possible to identify to species any of the fragmentary cephalopod remains in the diet of gentoo penguins in 1986; however, in 1994 the octopod Brachioteuthis picta was found in 3 samples from both penguin species while Kondakovia longimana and Martialia hyadesi were found in 6 and 2 samples, respectively, in the diet of macaroni penguins.

\section{Diet diversity and overlap}

In each of the seabird species studied there was only 1 prey species which contributed more than $5 \%$ by mass to the diet in both 1986 and 1994 (Fig. 3); these were Martialia hyadesi in both albatross species, krill in macaroni penguins and Champsocephalus gunnari in gentoo penguins. The diet diversity indices $(H)$ for both black-browed albatrosses and gentoo penguins were very similar in 1986 and 1994, whereas there was a greater diversity in the diet of grey-headed albatrosses and macaroni penguins in 1994 compared to 1986 (Fig. 3).

Dietary overlap in 1986 was much greater than in 1994 (Table 2), average values across all species being 0.55 and 0.20 , respectively. However, if macaroni penguin, the species whose diet changed most between 1986 and 1994 is excluded, the difference is somewhat reduced, being 0.51 and 0.36 , respectively. If greyheaded albatross, the species eating least krill, is excluded, then the difference is accentuated, the 1986 and 1994 values becoming 0.75 and 0.07 , respectively. Between the 2 albatross species, overlap in the 2 years was very similar, whereas between penguins it was reduced from 0.91 in 1986 to 0.08 in 1994. Overlap 

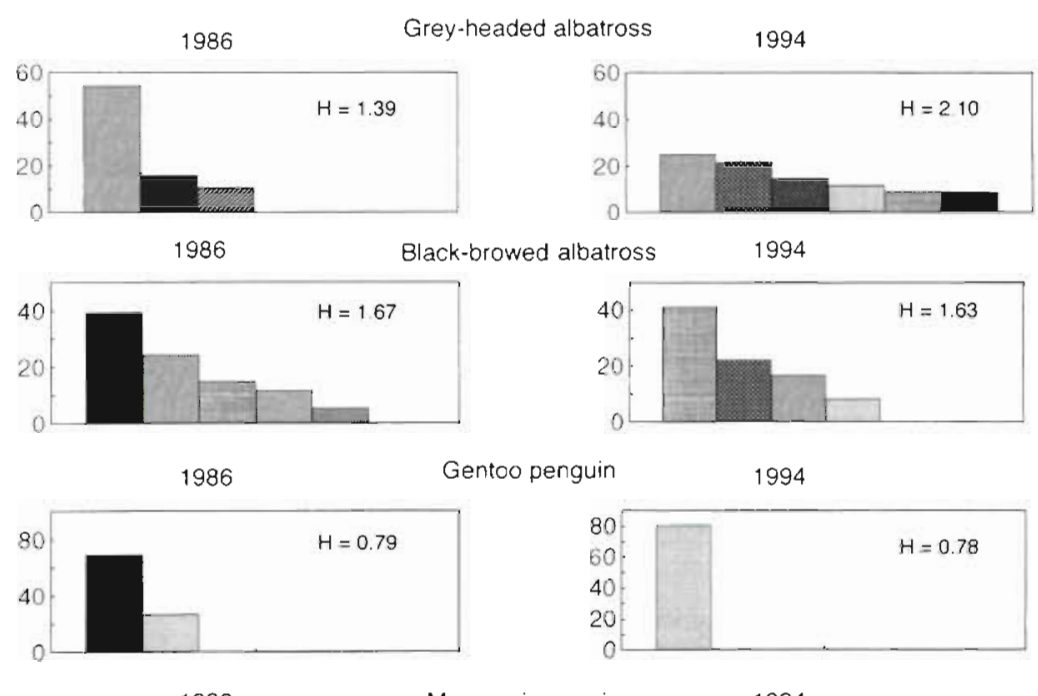

Gentoo penguin

1994
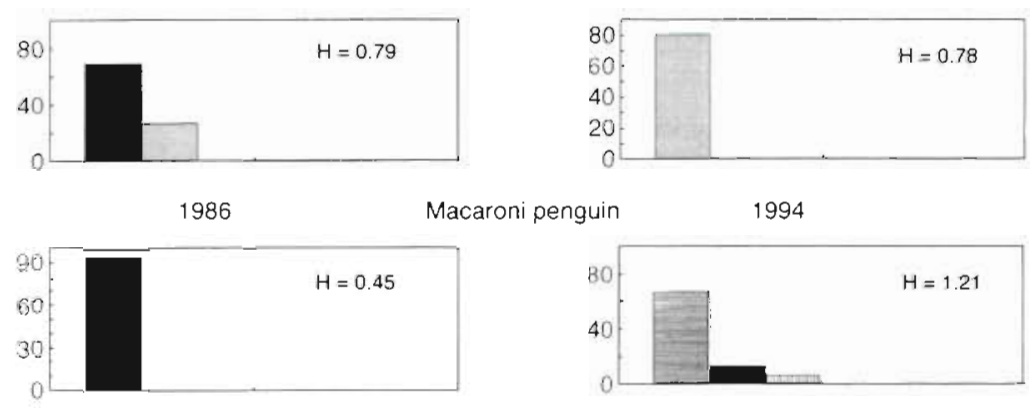

1994

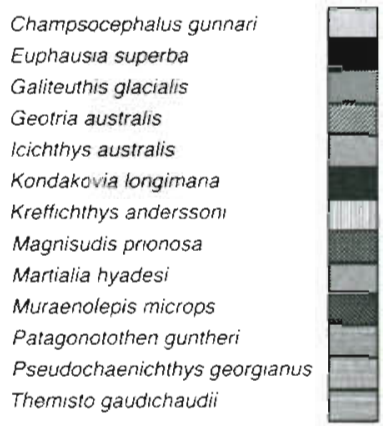

Fig. 3. Species composition by mass ( $>5 \%$ ) in the diets of grey-headed albatross, blackbrowed albatross, gentoo penguin and macaroni penguin during the breeding seasons of 1986 and 1994. Shannon-Weaver index of diversity $(H)$ is shown for each histogram

between black-browed albatrosses and penguins was also reduced by a similar amount. With grey-headed albatrosses, however, overlap in 1994 compared with 1986 decreased with macaroni penguins but remained similar with gentoo penguins. The overall average change in overlap, expressed as a proportionate change based on the 1986 values, was $52 \%(90 \%$ if grey-headed albatross is excluded and only $14 \%$ if macaroni penguin is excluded).

Taken together, these results suggest that the most decisive influence on the major decrease in dietary overlap in 1994 in comparison with 1986, was the switch in macaroni penguin diet from krill to amphipods, with the divergence in fish diet between black-browed albatrosses and gentoo penguins also contributing.

\section{Provisioning rate}

The rate at which energy is delivered by parents to offspring involves the size (and energy density) and frequency of meals.

\section{Meal size}

The mean mass of food samples obtained from greyheaded albatrosses was significantly greater in 1986 (Table 3), although there was no such difference $(280.5$
Table 2. Indices of dietary overlap in albatrosses and penguins in 1986 and 1994 at South Georgia. Values above the diagonal refer to 1986, values on the diagonal (bold type) are the overlap in the diet of each species between 1986 and 1994, and values below the diagonal are for 1994

\begin{tabular}{|lcccc|}
\hline & $\begin{array}{c}\text { Grey-headed } \\
\text { albatross }\end{array}$ & $\begin{array}{c}\text { Black-browed } \\
\text { albatross }\end{array}$ & $\begin{array}{c}\text { Macaroni } \\
\text { penguin }\end{array}$ & $\begin{array}{c}\text { Gentoo } \\
\text { penguin }\end{array}$ \\
\hline $\begin{array}{l}\text { Grey-headed } \\
\text { albatross }\end{array}$ & $\mathbf{0 . 5 8}$ & 0.64 & 0.23 & 0.22 \\
$\begin{array}{l}\text { Black-browed } \\
\text { albatross } \\
\begin{array}{l}\text { Macaroni } \\
\text { penguin } \\
\text { Gentoo }\end{array}\end{array}$ & 0.68 & 0.24 & 0.65 & 0.68 \\
penguin & 0.03 & 0.04 & 0.21 & 0.91 \\
\hline
\end{tabular}

vs $\left.269.0 \mathrm{~g} ; F_{(1.75)}=0.18, \mathrm{~ns}\right)$ when this comparison was restricted to the mass of solid remains which typically comprises about half each meal (Prince 1980b). The meal sizes in both years were smaller than the mean between 1976 and 1980, although this may reflect more extended sampling periods in the other years (e.g. in 1986 the mean mass of samples collected between February and May was $601 \mathrm{~g}$ (Croxall et al. 1988) compared to $528 \mathrm{~g}$ for February only (the data used in this study). In samples from black-browed albatrosses there was no significant difference between years in the mass of food delivered, in either overall mass (Table 3) or as solid remains (242.2 vs $232.5 \mathrm{~g} ; F_{(1,79)}=0.14$, ns). 
Table 3. Mass $(\mathrm{g})$ of meals delivered to chicks of albatrosses and penguins at South Georgia in 1986 and 1994 and in other years $\mathrm{n}=$ number of samples. Values of the $F$-statistic (from 1-way ANOVA using meal masses from both years) are given with the level of significance $(" p<0.05, \cdots p<0.01)$

\begin{tabular}{|c|c|c|c|c|c|c|c|c|}
\hline Species & Year & $\mathrm{n}$ & Mean & $\mathrm{SE}$ & Min. & Max. & $F$ & $\mathrm{p}$ \\
\hline Grey-headed albatross & $\begin{array}{c}1986 \\
1994 \\
\text { Other }\end{array}$ & $\begin{array}{l}40 \\
37\end{array}$ & $\begin{array}{l}527.5 \\
423.1 \\
602.0\end{array}$ & $\begin{array}{l}29.0 \\
26.8\end{array}$ & $\begin{array}{l}121 \\
113\end{array}$ & $\begin{array}{r}1080 \\
780\end{array}$ & 6.94 & $\cdot$ \\
\hline Black-browed albatross & $\begin{array}{c}1986 \\
1994 \\
\text { Other }^{b}\end{array}$ & $\begin{array}{l}43 \\
38\end{array}$ & $\begin{array}{l}414.3 \\
397.4 \\
462.0\end{array}$ & $\begin{array}{l}25.2 \\
31.5\end{array}$ & $\begin{array}{r}100 \\
36\end{array}$ & $\begin{array}{l}910 \\
820\end{array}$ & 0.18 & ns \\
\hline Gentoo penguin & $\begin{array}{c}1986 \\
1994 \\
\text { Other }\end{array}$ & $\begin{array}{r}40 \\
26 \\
238\end{array}$ & $\begin{array}{r}868.8 \\
82.0 \\
536.0\end{array}$ & $\begin{array}{l}41.4 \\
14.5 \\
39.3\end{array}$ & $\begin{array}{r}340 \\
7 \\
15\end{array}$ & $\begin{array}{r}1240 \\
256 \\
1275\end{array}$ & 222.01 & * \\
\hline Macaroni penguin & $\begin{array}{c}1986 \\
1994 \\
\text { Other }\end{array}$ & $\begin{array}{r}40 \\
40 \\
240\end{array}$ & $\begin{array}{l}448.0 \\
275.9 \\
322.9\end{array}$ & $\begin{array}{l}39.3 \\
30.6 \\
11.2\end{array}$ & $\begin{array}{r}50 \\
21 \\
9\end{array}$ & $\begin{array}{r}1150 \\
853 \\
930\end{array}$ & 11.94 & * \\
\hline $\begin{array}{l}\text { 'Mean from } 5 \text { other year } \\
\text { 'Mean from } 3 \text { other year } \\
\text { 'Mean from } 6 \text { other year }\end{array}$ & $\begin{array}{l}\text { is betwee } \\
\text { is betwe } \\
\text { s betwee }\end{array}$ & $\begin{array}{l}76 \text { and } \\
76 \text { and } \\
39 \text { and }\end{array}$ & & & & & & \\
\hline
\end{tabular}

In contrast, meals delivered to penguin chicks were very significantly smaller in 1994 than 1986 (Table 3) and also when compared with the average from 11-13 other years between 1977 and 1995 (Croxall et al. 1988 and BAS unpublished data). The difference between years was, however, much greater for gentoo penguins (1994 meal mass only $9 \%$ of that in 1986) than for macaroni penguins (1994 meal mass $62 \%$ of 1986 values).

\section{Meal frequency}

For penguins, the interval between the delivery of successive feeds to the chick by an individual bird was slightly, but not significantly, longer in 1994 than 1986. Gentoo penguin foraging trips in 1986 lasted $9.8 \pm 2.7 \mathrm{~h}$ ( $\mathrm{n}=128)$ compared with $12.1 \pm 3.6 \mathrm{~h}(\mathrm{n}=40)$ in 1994 . Macaroni penguin trips are bimodal and in 1986 lasted either $11.8 \pm 2.1 \mathrm{~h}(\mathrm{n}=130)$ or $28.2 \pm 5.5 \mathrm{~h}(\mathrm{n}=52)$, compared with $12.5 \pm 2.5 \mathrm{~h}(\mathrm{n}=30)$ or $30.7 \pm 6.2(\mathrm{n}=15)$ in 1994 (Croxall et al. 1988 and BAS unpubl. data).

For albatrosses, foraging trips by both species normally last approximately $48 \mathrm{~h}$ and are not significantly different between species (Pennycuick et al. 1984, Croxall et al. 1988, P. A. Prince unpubl. data). In 1994 however, the duration of trips was significantly longer, at $94.4 \pm 75.4 \mathrm{~h}(\mathrm{n}=79)$, being almost double the 1986 value of $52.2 \pm 36.8 \mathrm{~h}(\mathrm{n}=41)$.

The mean duration of foraging trips in Antarctic fur seals was also exceptionally long in 1994, being in excess of $14 \mathrm{~d}$ (I. L. Boyd unpubl. data), compared with a mean of $4.6 \mathrm{~d}$ for the 10 yr 1984 to 1993 and $3.7 \pm$
$1.1 \mathrm{~d}(\mathrm{n}=168)$ in 1986 (Croxall et al. 1988 and BAS unpubl. data).

\section{Provisioning rate}

Combining data on meal frequency, meal size and energy density of meals (using composition data and mean energy density of main prey-see Croxall et al. 1984) enables estimation of the rates of energy delivery by parents to offspring in 1986 and 1994 (Table 4).

This indicates that rates in 1994 were about one-half those in 1986 for grey-headed albatross, black-browed albatross and macaroni penguin and about one-tenth for gentoo penguin. For the albatrosses the differences mainly relate to meal frequency, for the penguins to meal size.

\section{Population size and breeding success}

In 1994, study populations of all seabird species and of Antarctic fur seal had substantially fewer individuals breeding than in 1986 (Table 5). Furthermore, the breeding populations in 1994 were well below the mean values from the long term (10 to 20 yr) records, whereas 1986 values were all above this average. In 1994, all species also had fewer breeding individuals than in 1993, though only for gentoo penguin (18\% fewer) and grey-headed albatross (17\% fewer) were the differences substantial. The relatively reduced population of the latter species is purely due to the 
Table 4. Provisioning rates to offspring of study species at Bird Island, South Georgia in 1986 and 1994

\begin{tabular}{|c|c|c|c|c|c|c|}
\hline Species & Year & $\begin{array}{c}\text { Prey mean } \\
\text { energy density }\left(\mathrm{kJ} \mathrm{g}^{-1}\right)\end{array}$ & Mass $(g)$ & $\begin{array}{l}\text { Meal } \\
\text { Energy content }(k J)\end{array}$ & Frequency $\left(\mathrm{d}^{-1}\right)$ & $\begin{array}{l}\text { Provisioning } \\
\text { rate }\left(\mathrm{kJ} \mathrm{d}^{-1}\right)\end{array}$ \\
\hline Grey-headed albatross & $\begin{array}{l}1986 \\
1994\end{array}$ & $\begin{array}{l}3.678 \\
3.787\end{array}$ & $\begin{array}{l}527.5 \\
423.1\end{array}$ & $\begin{array}{l}1940 \\
1602\end{array}$ & $\begin{array}{l}1.0 \\
0.5\end{array}$ & $\begin{array}{r}1940 \\
801\end{array}$ \\
\hline Black-browed albatross & $\begin{array}{l}1986 \\
1994\end{array}$ & $\begin{array}{l}3.964 \\
3.873\end{array}$ & $\begin{array}{l}414.3 \\
397.4\end{array}$ & $\begin{array}{l}1642 \\
1539\end{array}$ & $\begin{array}{l}1.0 \\
0.5\end{array}$ & $\begin{array}{r}1642 \\
769\end{array}$ \\
\hline Gentoo penguin & $\begin{array}{l}1986 \\
1994\end{array}$ & $\begin{array}{l}4.232 \\
4.000\end{array}$ & $\begin{array}{r}868.0 \\
82.0\end{array}$ & $\begin{array}{r}3673 \\
328\end{array}$ & $\begin{array}{l}2.0 \\
2.0\end{array}$ & $\begin{array}{r}7346 \\
656\end{array}$ \\
\hline Macaroni penguin & $\begin{array}{l}1986 \\
1994\end{array}$ & $\begin{array}{l}4.341 \\
4.128\end{array}$ & $\begin{array}{l}448.0 \\
275.9\end{array}$ & $\begin{array}{l}1945 \\
1065\end{array}$ & $\begin{array}{l}1.2 \\
1.1\end{array}$ & $\begin{array}{l}2334 \\
1172\end{array}$ \\
\hline
\end{tabular}

Table 5. Population size (pairs of seabirds, number of parturient female fur seals), breeding success (\% chicks fledged per egg laid $_{i}$ proportion of pups surviving to $6-8 \mathrm{wk}$ of age) and mass $(\mathrm{kg})$ of offspring at independence for albatrosses, penguins and Antarctic fur seal in study colonies/areas at Bird Island, South Georgia in 1986 and 1994. Mean shows value for all years for which data are available. (sample size [number of years of data]; and SE, and range shown in parentheses). Data from Croxall et al. (1988), Boyd et al. (1995) and BAS unpubl. data

\begin{tabular}{|c|c|c|c|c|}
\hline Species & Year & Population size & Breeding success & Fledging/weaning mass \\
\hline Grey-headed albatross & $\begin{array}{l}1986 \\
1994 \\
\text { Mean }\end{array}$ & $\begin{array}{c}384 \\
209 \\
307(17 ; 20.5,155-451)\end{array}$ & $\begin{array}{c}60.2 \\
27.0 \\
37.6(17 ; 4.1,4.5-59.7)\end{array}$ & $\begin{array}{c}3.56 \\
2.86(4 ; 0.06,2.50-3.26) \\
3.77(168[6] ; 0.18,0.56-5.60)\end{array}$ \\
\hline Black-browed albatross & $\begin{array}{c}1986 \\
1994 \\
\text { Mean }\end{array}$ & $\begin{array}{c}183 \\
102 \\
147(17 ; 13.4,16-253)\end{array}$ & $\begin{array}{c}31.1 \\
2.9 \\
26.5(17 ; 5.5,0-63.3)\end{array}$ & $\begin{array}{c}\text { no data } \\
4.23(5 ; 0.18,3.90-4.80) \\
3.76(152[6] ; 0.06,1.90-4.84)\end{array}$ \\
\hline Gentoo penguin & $\begin{array}{l}1986 \\
1994 \\
\text { Mean }\end{array}$ & $\begin{array}{c}3738 \\
2769 \\
3521(16 ; 269,1155-6350)\end{array}$ & $\begin{array}{c}42.0 \\
4.0 \\
42.2(16 ; 6,0-80)\end{array}$ & $\begin{array}{c}\text { no data } \\
5.07(100 ; 0.01,3.30-6.60) \\
5.47(493[6] ; 0.03,1.80-7.45)\end{array}$ \\
\hline Macaroni penguin & $\begin{array}{c}1986 \\
1994 \\
\text { Mean }\end{array}$ & $\begin{array}{c}1350 \\
912 \\
1124(17 ; 52,624-1517)\end{array}$ & $\begin{array}{c}50.0 \\
46.0 \\
46.8(17 ; 4,9-67)\end{array}$ & $\begin{array}{c}\text { no data } \\
2.91(100 ; 0.05,1.40-4.60) \\
3.26(599[6] ; 0.02,1.80-4.40)\end{array}$ \\
\hline \multirow[t]{3}{*}{ Antarctic fur seals } & 1986 & 854 & 0.78 & $\begin{array}{l}\sigma^{7} 14.8(70 ; 0.26,9.0-21.0) \\
912.6(42 ; 0.20,10.4-16.2)\end{array}$ \\
\hline & 1994 & 714 & 0.35 & $\begin{array}{l}\text { of } 11.9(33 ; 0.31,8.2-15.0) \\
\text { Q } 10.7(67 ; 0.23,6.5-15.6)\end{array}$ \\
\hline & Mean & $762(9 ; 31,545-854)$ & $0.78(9 ; 0.03,0.68-0.93)$ & $\begin{array}{l}\text { o } 13.5(519[13] ; 0.32,11.2-15.0) \\
\circ 11.8(566[13] ; 0.21,9.9-12.8)\end{array}$ \\
\hline
\end{tabular}

existence of 2 alternating demipopulations in this biennially breeding species (Croxall et al. 1998).

In terms of breeding success over a 19 yr period at the same study colonies (Table 5), 1986 was a year of average (gentoo penguin, Antarctic fur seal) or better than average (macaroni penguin, black-browed and grey-headed albatrosses) performance for all species. In contrast, in 1994, black-browed albatross and gentoo penguin populations suffered almost complete reproductive failure, with only $4 \%$ and $3 \%$ of eggs, respectively, producing fledged chicks. Grey-headed albatrosses had slightly ( $7 \%$ ) lower breeding success than usual, whereas that of macaroni penguins was essentially unchanged.

For those offspring that survived, we can use data on their mass at independence (Table 5) to assess their condition at this time, and, indirectly, their potential for subsequent survival. For gentoo and macaroni penguins the mean fledging mass in 1994 was significantly lower than the overall mean value between 1989 and 1995 ( 1 -way ANOVA: gentoo $F_{(1,591)}=34.68, p<0.001$; macaroni $\left.F_{(1,697)}=64.52, \mathrm{p}<0.001\right)$. Weaning mass of Antarctic fur seal pups in 1994 was lower than both the overall mean (from 13 other years, 1 -way ANOVA: of $\left.F_{(1.597)}=21.74, \mathrm{p}<0.001 ; \mathrm{Q} F_{(1,584)}=18.54, \mathrm{p}<0.001\right)$ and the value for 1986 (1-way ANOVA: $\sigma^{7} F_{(1,101)}=$ $47.56, \mathrm{p}<0.001 ;$ o $\left.F_{(1.107]}=34.98, \mathrm{p}<0.001\right)$. Greyheaded albatross chicks attained a lower peak mass in 1994 compared to $1986\left(t_{22}=7.30, p<0.05\right)$ and were significantly lighter at fledging in 1994 than the mean value for 1989 to 1995 (1-way ANOVA: $F_{(1,170)}=4.74$, $\mathrm{p}<0.05$ ). In contrast, the 5 surviving black-browed 
albatross chicks attained a heavier, but not significantly so (1-way ANOVA: $F_{(1,155)}=2.66$, ns), average mass than the mean value between 1989 and 1995 .

\section{DISCUSSION}

\section{Prey availability in 1986 and 1994}

In 1994, acoustic transect surveys to assess distribution and to estimate biomass of krill were carried out in areas to the northeast and northwest of South Georgia (Brierley \& Watkins 1996). The westernmost of these areas lies immediately to the northwest of Bird Island and falls within the main foraging grounds of Bird Island populations of Antarctic fur seal (Boyd et al. 1998), black-browed albatross (Prince et al. 1998) and macaroni penguin (Trathan et al. 1998) and part of the foraging areas of grey-headed albatross (Prince et al. 1998). Although gentoo penguin foraging is restricted to inshore areas (Williams 1991, Williams et al. 1992a, b) and does not overlap with the survey area, this penguin nevertheless depends for its krill prey on supplies advected from adjacent offshore areas.

The 1994 survey showed krill to be very scarce; at only $7.4 \mathrm{~g} \mathrm{~m}^{-2}$ (wet mass), abundance was the second lowest in the 11 yr time series since 1981 (Brierley et al. 1998). About $73 \%$ by mass of acoustic targets were zooplankton smaller than krill, which net hauls revealed to be principally the amphipod Themisto gaudichaudii and copepods (Brierley \& Watkins 1996). In 1994 the krill taken by nets were strongly bimodal, with the main modes at ca 40 and $50 \mathrm{~mm}$. A similar, though less marked, bimodality characterised the predator samples taken at the time of the main nethaul collection (mid-January) but the larger mode had virtually disappeared from predator samples by early February (Reid et al. in 1999).

In 1986, acoustic surveys of krill distribution and abundance were carried out as radial transects (with a centre of origin at Bird Island), commencing 10 to $15 \mathrm{~km}$ offshore from Bird Island and extending to $135 \mathrm{~km}$ distance (see Hunt et al. 1992, Veit et al. 1993). This survey, covering some $45000 \mathrm{~km}^{2}$, therefore also covered the foraging areas of the Bird Island populations of the predators in the study to a broadly similar extent as the 1994 survey. The 1986 survey showed krill to be widespread and abundant (see, e.g., Veit et al. 1993 Fig. 9 therein), with a biomass of $29.7 \mathrm{~g} \mathrm{~m}^{-2}$ (C. Goss unpubl. data) and forming $>75 \%$ of zooplankton targets. Krill taken by nets had more individuals of smaller sizes, fewer of the larger sizes and fewer sexually mature females than those taken by predators, but were otherwise similar (Hill et al. 1996, Reid et al. 1996b).
Although it is clear that the 1986 krill biomass was about (or at least) 4 times greater than in 1994, comparing the overall krill biomass in these 2 years is complicated by differences in survey design, acoustic equipment, and methods of data processing and analysis.

The area to the northwest of South Georgia was also surveyed in 1996 using equipment and analysis techniques similar to those employed in 1994; this produced an estimate of krill biomass of $26.7 \mathrm{~g} \mathrm{~m}^{-2}$ (Brierley et al. 1997). In terms of predator performance, 1996 was very much closer to 1986 than to 1994 . Thus in 1996 breeding success was similar to (grey-headed albatross, macaroni penguin and Antarctic fur seal at 56, 48 and $80 \%$ respectively), or better than (blackbrowed albatross and gentoo penguin at 45 and $79 \%$ respectively) the overall average (up to 1995) and the values for 1986 (Table 5). Similarly, fledging/weaning masses were $9 \%$ (macaroni penguin), $11 \%$ (female Antarctic fur seal pups), $17 \%$ (gentoo penguin) and $20 \%$ (male fur seal pups) greater than in 1994 and close to the multi-year average (Table 5 and BAS unpubl. data).

Overall, therefore, we can reasonably conclude on the basis of both absolute and circumstantial evidence that the abundance of krill around northwest South Georgia was at least 4 times greater in 1986 than 1994 . and that its availability to predators differed commensurately in these 2 years.

\section{Predator responses to prey availability in 1986 and 1994}

Some of the main differences between predator diet and breeding performance in 1986 and 1994 are summarised in Table 6.

Diet

The amount (by mass) of krill in the diet of predators in 1994 was reduced by 88 to $90 \%$, with compensatory increases in fish (all species) and squid (albatrosses only). The diversity of prey in the diet increased for grey-headed albatross (greater variety of fish species) but not black-browed albatross (though the fish species differed between the 2 years). Gentoo penguin diet diversity remained the same, chiefly because at South Georgia this species basically eats only icefish and krill, with just the proportions changing. Only macaroni penguin diet changed substantially, principally due to the scarcity of krill and the abundant presence of Themisto gaudichaudii, together with small quantities of other non-krill crustaceans (and various fish species) in 1994 
Table 6. Differences in diet, provisioning of offspring and breeding success of study species of seabirds and seals between 1986 and 1994. Values are those for 1994 expressed as a percentage of 1986

\begin{tabular}{|c|c|c|c|c|c|c|c|c|c|c|}
\hline \multirow[t]{2}{*}{ Species } & \multicolumn{3}{|c|}{ Diet composition } & \multicolumn{2}{|c|}{ Diet indices } & \multicolumn{3}{|c|}{ Provisioning } & \multirow{2}{*}{$\begin{array}{c}\text { Breeding } \\
\text { success }\end{array}$} & \multirow{2}{*}{$\begin{array}{c}\text { Fledge/wean } \\
\text { mass }\end{array}$} \\
\hline & Krill & Fish & Squid & Diversity & Overlap & Meal size & Frequency & Rate & & \\
\hline Grey-headed albatross & 9 & 122 & 153 & 151 & & 80 & 53 & 41 & 45 & 80 \\
\hline Black-browed albatross & 12 & 141 & 174 & 98 & $\begin{array}{l}106 \\
15^{a}\end{array}$ & 96 & 53 & 47 & 9 & $112^{\mathrm{b}}$ \\
\hline Gentoo penguin & 13 & 136 & 0 & 99 & 9 & 9 & 78 & 9 & 10 & $93^{b}$ \\
\hline $\begin{array}{l}\text { Macaroni penguin } \\
{ }^{a} \text { For black-browed albat } \\
{ }^{b} \text { Compared to mean of a }\end{array}$ & $\begin{array}{l}14 \\
\text { tross } \mathrm{v} \\
\text { tll othe }\end{array}$ & $\begin{array}{l}115 \\
\text { smac } \\
\text { mea }\end{array}$ & $\begin{array}{l}0 \\
\text { oni pe } \\
\text { see } T\end{array}$ & $\begin{array}{l}269 \\
\text { in value } i \\
5 \text { ), as no }\end{array}$ & $\begin{array}{l}6 \text {; avera } \\
\text { data wer }\end{array}$ & $\begin{array}{l}62 \\
\text { of all } 6 \text { pai } \\
\text { vailable for }\end{array}$ & $\begin{array}{l}\quad 93 \\
\text { rise compa } \\
986\end{array}$ & $\begin{array}{l}50 \\
\text { arison }\end{array}$ & $\begin{array}{r}92 \\
\text { is } 38\end{array}$ & $89^{b}$ \\
\hline
\end{tabular}

Dietary overlap indices in 1986 and 1994 were very similar for the 2 albatross species, but overlaps were greatly reduced in 1994 for all comparisons between albatrosses and penguins and between macaroni and gentoo penguins (Table 6). This suggests that in years of high krill availability, its abundance may be such that apparently high levels of dietary overlap can be sustained without causing substantial interspecies competition. In years of lower availability of krill, however, the differences in diet are accentuated, suggesting a reflection of increased interspecies competition under these circumstances.

\section{Provisioning}

All the study species show biparental care throughout most (in macaroni penguins the males undertake all the brooding care) or all of the chick-rearing period. In terms of the performance of parents during the part of this period covered by the study (Table 6), meal size was similar between years in black-browed albatross, somewhat smaller in 1994 in other species (least so in grey-headed albatross), and differed most (by $91 \%$ ) in gentoo penguins. The intervals between meals were longer in all species in 1994. In the penguins, however, differences were small for macaroni penguin and although greater for gentoo penguin each chick still received one meal per day, the same as in 1986 and in all other years studied (Williams \& Rothery 1990). In the albatrosses, however, feeding intervals were doubled in 1994. Taken together (see Table 4), the rate of energy delivery to offspring in 1994 compared to 1986 was reduced by $90 \%$ in gentoo penguins (mainly through the reduction in meal size) and by 40 to $50 \%$ in the other 3 species, mainly through reduced meal size in macaroni penguin and by increased duration of foraging trips in the albatrosses. Thus, in general, alba- trosses maintained meal size at the expense of trip duration, whereas penguins maintained trip duration at the cost of bringing back much smaller meals.

\section{Breeding success}

The overall data on breeding success (Table 6) indicate that there is not a proportionate (linear) transformation of provisioning rate into breeding success. Thus similar 50 to $60 \%$ reductions in provisioning rates in the 2 albatross species result in an order of magnitude $(91 \%)$ reduction in breeding success of blackbrowed albatross but only a halving in grey-headed albatross. This is in accord, however, with the much greater dependence on krill of black-browed albatrosses, the much reduced tolerance of black-browed albatross chicks (with faster growth rates and $25 \%$ shorter fledging period) to fluctuations in food supply and the greater adaptation of grey-headed albatross chicks to a low energy diet (Prince 1980b. Prince \& Ricketts 1981, Reid et al, in press).

Gentoo penguins show a reduction in breeding success $(90 \%)$ equivalent to that of black-browed albatrosses. Their sensitivity to changes in krill availability may reflect their very limited foraging range (probably within $10 \mathrm{~km}$ of the colony throughout the year (Williams 1991, Williams et al. 1992a, b) and their inability to increase their intake of fish sufficiently to compensate (i.e. they could only bring meals of $10 \%$ of normal mass to their chicks in 1994).

In contrast, macaroni penguins show a reduced overall provisioning rate (similar to albatrosses) but only suffer a small reduction in breeding success. They appear to achieve this by virtue of switching from a diet of predominantly krill to one that mainly comprises amphipods. Such prey are about the same size as the smaller krill that make up a proportion of their diet (im- 
portant numerically but much less so in terms of mass) in normal years. However, values for breeding success relate to the number of chicks fledged and not to their subsequent survival. Although the 5 surviving blackbrowed albatross chicks were all at a mass typical of normal years, chicks/pups of all other species were 7 to $20 \%$ lighter. The fledging mass of macaroni penguin chicks was the lowest in 8 yr of study so their relatively high breeding success may not necessarily be a good reflection of overall success in terms of fledglings becoming yearlings (see Sagar \& Horning 1998).

Of other species, Antarctic fur seals showed reduced frequency of occurrence of krill (and more fish), very long foraging trip durations (nearly one order of magnitude greater than in 1986) and high pup mortality (2 to 3 times the rate of typical years), with surviving pups being $15 \%$ (females) to $20 \%$ (males) lighter than in 1986. Antarctic prions, whose diet was sampled in both 1986 and 1994 switched from chiefly krill (>50\% by mass) in 1986 to copepods/amphipods (>90\% by mass) in 1994 and maintained performance in terms of chick growth rates and productivity (Liddle 1994, Reid et al. 1997, 1999).

We are now able to address the 3 questions posed initially. First, the differences in krill availability in 1986 and 1994 are well reflected in the diet of study predators, particularly those mainly dependent on krill (black-browed albatross, gentoo and macaroni penguins and Antarctic fur seals). Second, the only predator in the main study that was able to compensate, at least in part, for the low availability of krill by prey switching was macaroni penguin. This species took substantial quantities of the amphipod Themisto gaudichaudii-as it also did in some other years of low krill availability (e.g. 1991, BAS unpublished data). Antarctic prions also switched to a copepod/amphipod diet and maintained productivity. Third, against this background, the breeding performances in 1994 of the other 2 species most dependent on krill, black-browed albatross and gentoo penguin, were about $10 \%$ of that in 1986, with a diet whose krill contribution was reduced to $10 \%$ of that in 1986 . In the case of the penguins the decisive factor in reduced breeding performance was the small size of meals; in the case of the albatrosses it was the reduced frequency of delivery. In all species, however, the overall effect of the low krill availability was probably worse than indicated due to the potentially reduced survival of offspring which became independent at significantly lower masses than usual. In addition, reductions in adult survival may be inferred from the failure of breeding populations to recover in 1995 and 1996 to the numbers in or before 1994. Thus the study population of macaroni penguins remained at 640 pairs in 1995/96 (compared with 912 and 642 in 1993/94 and 1994/5 respectively) and gentoo penguin populations had only recovered from 2152 pairs in 1994/95 to 2404 pairs in 1995/96 (compared with 3405 and 2796 pairs in $1992 / 93$ and 1993/94 respectively). For black-browed albatrosses the study population dropped to 15 pairs in 1994/95 before recovering to 82 pairs in 1995/96 (compared with 110 and 102 pairs in $1992 / 93$ and $1993 / 94$ respectively).

\section{Comparisons with results of similar studies}

There are many studies of seabirds which have shown that marked reductions in breeding success are usually accompanied by some combination of smaller and/or less frequent meals. In this study, however, we are solely interested in the results of other studies where these have investigated the responses of different species of seabirds to changes in prey abundance; there are rather few of these.

The nature of the responses of different species should be viewed in the light of the expectation that species with different characteristics are likely to have different functional responses to changes in prey abundance. In particular, the most direct and straightforward responses are likely to come from species: (1) with a specialised diet and little ability or opportunity to switch to other prey, and/or (2) with relatively restricted access to prey, whether in terms of feeding habit (e.g. especially surface feeders vs diving species) or foraging range.

Other adaptations have also been suggested as predisposing species to larger and quicker responses to changes in prey, including costs of foraging (e.g. flapping vs gliding flight), behavioural buffers (e.g. amount of non-foraging time which could be used for foraging in a year of low prey abundance) and extent of chick tolerance of food shortage (Furness \& Ainley 1984, Cairns 1987). However relatively few empirical data are available on any of these topics and while plausible, they remain to be critically investigated.

Our South Georgia studies clearly support the contention that species such as macaroni penguin, which can switch prey, are more readily buffered against the direct impact of changes in their normal (or alternate) diet than species which cannot, even when of similar feeding habit (e.g. gentoo penguin). The inability of the other species to compensate more effectively for the lack of krill probably relates to (1) inability to costeffectively exploit prey as small as amphipods for the larger predator species (gentoo penguin, albatrosses, fur seals) and/or (2) low densities/encounter rates. with alternative prey (e.g. fish) in habitats restricted horizontally (gentoo penguin) or vertically (albatrosses). 
There is additional evidence relating to the effects of restrictions in access to prey. Thus penguins appear reluctant to increase foraging trip duration at the expense of meal size, presumably because travel time is already severely constrained by their flightless habit and resulting high costs of transport. In contrast, albatrosses readily extend trip duration, presumably because the low travel costs of high speed gliding flight mean they can easily and economically return to their offspring once they have acquired sufficient food to make the trip worthwhile. Their constraint, however, is presumably the low encounter rate with suitable prey in an essentially 2-dimensional habitat from which prey can readily escape by downward movement. In contrast, penguins' diving and swimming capabilities make them well able to follow profitable patches of prey. Under the conditions of very low prey abundance in 1994, these different constraints combined to produce rather similar results, in terms of overall provisioning performance, for all 4 species.

The studies most comparable to ours are those carried out in Shetland, particularly in the years 1990 and 1991, the latter having a 40 -fold greater abundance of lesser sandeel Ammodytes marinus, the main prey of local seabirds (Table 7). Analysis of data prior to 1990 (Furness \& Barrett 1991) had indicated that relationships between reproductive performance and sandeel abundance were: (1) poor in great skua Catharacta skua, northern fulmar Fulmarus glacialis and northern gannet Morus bassanus because of prey switching, (2) poor in red-throated diver Gavia stellata, common shag Phalacrocorax aristotelis and common guillemot Uria aalge because they had access to benthic habitat, and, (3) better for the 5 remaining species, which formed a roughly graded sequence from Arctic tern Sterna paradisaea and Arctic skua Stercorarius parasiticus to kittiwake Rissa tridactyla, to razorbill Alca torda and to puffin Fratercula arctica.
The latter sequence is also roughly in relation to the degree of specialisation of diet, extent/distance of foraging and surface feeding versus diving capability. In general there were few differences in egg/clutch size and often little difference in hatching success, most of the responses showing up in the chick-rearing period. The detailed research in 1990 and 1991, however. tended to reveal a more complex picture, with clear responses for shags (Monaghan 1996) and common guillemot (Monaghan et al. 1994, Uttley et al. 1994) and egg and chick size differences in Arctic tern (Suddaby \& Ratcliffe 1997) - the latter being consistent with effects commonly detected in studies of gulls (review in Pierotti \& Annett 1990).

For no species involved (Table 7) was there evidence of a switch in diet away from sandeels in 1990 (though the characteristics of this prey differed somewhat between years). The differences in fledging success between years were very marked and this was the main contributor to the overall difference in breeding success. At least as evidenced by change in foraging trip duration, provisioning rate changed substantially between the 2 years. For the common guillemot there was additional evidence of change in the amount of time spent foraging (i.e. not in the colony), in time spent diving and in the number of dives per bout, indicating that it was able to adjust foraging behaviour and time budgets in response to food abundance but not sufficiently to cope with the low food availability in 1990 (Monaghan et al. 1994). The results for kittiwake are similar to those found by Regehr \& Montevecchi (1997) in Newfoundland in comparing 1992 and 1993, years of low and high food availability respectively. In 1992 more 1 -egg clutches were laid, egg volumes were smaller (but not significantly so) and hatching success was similar, but fledging success was only $7 \%$ (compared with $68 \%$ in 1993). However, Regehr \& Montevecchi (1997) noted that part of the difference in breed-

Table 7. Chick characteristics, breeding success and provisioning in Shetland seabirds in 1990 and 1991, respectively years of low and high availability of lesser sandeel. Differences shown are for 1990 expressed as a percentage of 1991. Differences significant at $\mathrm{p}<0.05$ are indicated; $n d=$ no significant difference

\begin{tabular}{|c|c|c|c|c|c|c|c|c|c|c|c|c|}
\hline \multirow[t]{2}{*}{ Variable } & \multicolumn{3}{|c|}{ European shag } & \multicolumn{3}{|c|}{ Arctic tern } & \multicolumn{3}{|c|}{ Kittiwake } & \multicolumn{3}{|c|}{ Common guillemot } \\
\hline & 1990 & 1991 & Diff. & 1990 & 1991 & Diff. & 1990 & 1991 & Diff. & 1990 & 1991 & Diff. \\
\hline Clutch size & & & & 1.5 & 1.9 & $79^{\circ}$ & & & nd & & & \\
\hline Egg volume (m) & & & & 16.2 & 16.9 & $96^{*}$ & & & & & & \\
\hline Hatch success & & & & & & & 81 & 80 & & 76 & 72 & 105 \\
\hline Fledge success & & & & & & & 0 & 85 & $\cdot$ & 78 & 98 & $80^{\circ}$ \\
\hline Breeding success & 0.7 & 1.25 & $56^{\circ}$ & 0 & 70 & $\cdot$ & 0 & 68 & $\cdot$ & 59 & 70 & 85 \\
\hline Fledge period (d) & & & & & & & & & & 24.3 & 21.5 & $113^{*}$ \\
\hline Foraging trip (h) & & & & & & & & & & & & \\
\hline Incubation & & & & & & & 4.2 & 14.7 & $29^{\circ}$ & 13 & 9 & $144^{\circ}$ \\
\hline Chick-rearing & 2.9 & 1.0 & $290^{\circ}$ & & & & 2.1 & 6.2 & $34^{*}$ & 178 & 76 & $234^{\circ}$ \\
\hline
\end{tabular}


ing success resulted from increased predatory activities of gulls in the year of low marine food availability

Despite this caution, however, a reasonably coherent picture of relationships between differences in provisioning rate and productivity is developing with respect to years of high and low availability of prey to seabirds. Key variables determining the nature of species' responses certainly include the degree of dietary specialisation (and availability of alternative prey) and restrictions in foraging habitat, especially in terms of trade-offs between foraging adaptations, costs of transport and rates of encountering prey. Detailed multispecies studies over consecutive years are well-placed to refine the nature of the responses, particularly to prey shortage. It is important that as many as possible of the key variables (population size, diet, hatching and fledging success, meal mass and frequency) should be measured for each species.

In these circumstances a clear picture should emerge of differences in reproductive performance and success in relation to major (e.g. order of magnitude) changes in prey abundance/availability. However, for many purposes, and especially for using indices of predator performance in the context of the management of marine systems - particularly where fisheries resources are involved-it is vital to have measures of prey abundance/availability independent of those of predators. A few studies have managed these in some years, but there are very few current studies able to relate a variety of indices of predator performance to estimates of prey abundance at spatio-temporal scales appropriate to estimating, or inferring, relationships between prey abundance and availability to predators.

Such studies are a pre-requisite for the quantitative description of the functional relationships necessary to allow data on seabird performance to be accepted as a valid accompaniment to - and even a substitute forconventional approaches to resource management in marine systems.

Acknowledgements. We thank all those who collected field data at Bird Island in 1986 and 1994, also those who collected and made available data on prey abundance in these years. In particular we are grateful to Ian Boyd, Andy Brierley and Cathy Goss for helpful discussions and comments on the manuscript. J.P.C. and K.R. dedicate this paper to the memory of Peter Prince, friend and mentor at Bird Island 1976-1998.

Appendix 1. Diets of 5 marine predators at Bird Island during February 1994

\begin{tabular}{|c|c|c|c|c|c|c|c|c|}
\hline \multirow{2}{*}{$\begin{array}{l}\text { Predator } \\
\text { Prey taxon }\end{array}$} & \multicolumn{2}{|c|}{ Occurrence } & \multicolumn{2}{|c|}{ Number } & \multicolumn{2}{|c|}{ Mass } & \multirow{2}{*}{$\begin{array}{l}\text { Total length (mm) } \\
\text { mean (range) }\end{array}$} & \multirow{2}{*}{$\begin{array}{c}\text { Mass (g) } \\
\text { mean (range) }\end{array}$} \\
\hline & $\mathrm{f}$ & $\%$ & $\mathrm{n}$ & $\%$ & g & $\%$ & & \\
\hline \multicolumn{9}{|l|}{ Grey-headed albatross } \\
\hline \multicolumn{9}{|l|}{$\begin{array}{c}\text { Crustaceans } \\
\text { Euphausids }\end{array}$} \\
\hline Euphausids & & & & & & & & \\
\hline \multirow{2}{*}{\multicolumn{9}{|c|}{$\begin{array}{l}\text { Euphausia superba } \\
\text { Decapods }\end{array}$}} \\
\hline & & & & & & & & \\
\hline Pasiphaea sp. & 10 & 27,0 & & & 74 & 0.8 & & \\
\hline Cephalopods & 20 & 54.0 & & & 3711 & 37.3 & & \\
\hline \multicolumn{9}{|l|}{ Onychoteuthidae } \\
\hline Kondakovia longimana & 4 & 10.8 & 5 & 8.1 & 847 & 8.5 & $322.0(151.3-461.0)$ & $524.3(14.3-1490.8)$ \\
\hline \multicolumn{9}{|l|}{ Omnastrephidae } \\
\hline Martialia hyadesi & 13 & 35.1 & 46 & 74.2 & 2489 & 25.0 & $214.3(172.1-249.4)$ & $167.3(63.0-280.1)$ \\
\hline \multicolumn{9}{|l|}{ Cranchiidae } \\
\hline Galiteuthis glacialis & 4 & 10.8 & 11 & 17.7 & 375 & 3.8 & $228.5(203.9-309.9)$ & $105.6(77.6-217.4)$ \\
\hline Fish & 28 & 75.7 & & & 6014 & 60.4 & & \\
\hline \multicolumn{9}{|l|}{ Petromyzontidae } \\
\hline Geotria a ustralis & 1 & 2.7 & 2 & 9.1 & 234 & 2.4 & & \\
\hline \multicolumn{9}{|l|}{ Microstomatidae } \\
\hline Nansenia antarctica & 1 & 2.7 & 1 & 4.5 & 42 & 0.4 & & \\
\hline \multicolumn{9}{|l|}{ Paralepididae } \\
\hline Magnisudis prionosa & 2 & 5.4 & 2 & 9.1 & 2152 & 21.6 & & $500^{\mathrm{a}}$ \\
\hline \multicolumn{9}{|l|}{ Myctophidae } \\
\hline Electrona antarctica & 1 & 2.7 & 1 & 4.5 & 12 & 0.1 & 67.8 & 4.2 \\
\hline Gymnoscopelus nicholsi & 1 & 2.7 & 1 & 4.5 & 60 & 0.6 & 163.8 & 27.8 \\
\hline Krefftichthys anderssoni & 1 & 2.7 & 2 & 9.1 & 6 & 0.1 & 72.3 & 2.9 \\
\hline Protomyctophum bolini & 1 & 2.7 & 2 & 9.1 & 2 & 0.0 & 50.9 & 1.1 \\
\hline \multicolumn{9}{|l|}{ Muraenolepididae } \\
\hline Muraenolepis microps & 2 & 5.4 & 2 & 6.5 & 1160 & 11.7 & $237.8(217.9-259.4$ & $269.9(199.2-340.5)$ \\
\hline \multicolumn{9}{|l|}{ Notothenidae } \\
\hline $\begin{array}{l}\text { Nototheniidae sp. } \\
\text { Channichthyidae }\end{array}$ & 1 & 2.7 & 1 & 4.5 & 13 & 0.1 & & \\
\hline
\end{tabular}


Appendix 1 (continued)

\begin{tabular}{|c|c|c|c|c|c|c|c|c|}
\hline \multirow{2}{*}{$\begin{array}{l}\text { Predator } \\
\text { Prey taxon }\end{array}$} & \multicolumn{2}{|c|}{ Occurrence } & \multicolumn{2}{|c|}{ Number } & \multicolumn{2}{|c|}{ Mass } & \multirow{2}{*}{$\begin{array}{l}\text { Total length }(\mathrm{mm}) \\
\text { mean (range) }\end{array}$} & \multirow{2}{*}{$\begin{array}{l}\text { Mass (g) } \\
\text { mean (range) }\end{array}$} \\
\hline & $\mathrm{f}$ & $\%$ & $\mathrm{n}$ & $\%$ & g & $\%$ & & \\
\hline \multicolumn{9}{|c|}{ Grey-headed albatross (continued) } \\
\hline $\begin{array}{l}\text { Champsocephalus gunnari } \\
\text { Pseudochaenichthys }\end{array}$ & 5 & 13.5 & 9 & 40.9 & 1443 & 14.5 & $240.6(134.5-327.2)$ & $84.0(9.3-208.8)$ \\
\hline georgianus & 1 & 2.7 & 1 & 4.5 & 890 & 8.9 & 384.9 & 413.4 \\
\hline \multicolumn{9}{|l|}{ Black-browed albatross } \\
\hline Crustaceans & 14 & 36.8 & & & 416 & 4.7 & & \\
\hline \multicolumn{9}{|l|}{ Amphipods } \\
\hline \multicolumn{9}{|l|}{ Euphausids } \\
\hline $\begin{array}{l}\text { Euphausia superba } \\
\text { Decapods }\end{array}$ & 9 & 23.7 & & & 395 & 4.5 & $40.7(40-42)(n=7)$ & \\
\hline Pasiphaea sp. & 1 & 2.6 & & & 21 & 0.2 & & \\
\hline \multicolumn{9}{|l|}{ Gonatidae } \\
\hline $\begin{array}{l}\text { Gonatus antarcticus } \\
\text { Onychoteuthidae }\end{array}$ & 1 & 2.6 & 1 & 2.6 & 107 & 1.2 & 269.6 & 370.1 \\
\hline Kondakovia Iongimana & 1 & 2.6 & 1 & 2.6 & 125 & 1.4 & 350.4 & 433.3 \\
\hline Moroteuthis knipovitchi & 1 & 2.6 & 1 & 2.6 & 6 & 0.1 & 173.4 & 23.7 \\
\hline \multicolumn{9}{|l|}{ Omnastrephidae } \\
\hline \multicolumn{8}{|l|}{ Cranchiidae } & $169.6 \quad(104.4-280.1)$ \\
\hline Galiteuthis glacialis & 5 & 13.2 & 10 & 26.3 & 305 & 3.5 & $230.2(197.7-248.7)$ & $105.5(71.9-126.9)$ \\
\hline \multicolumn{9}{|l|}{ Paralepididae } \\
\hline $\begin{array}{l}\text { Magnisudis prionosa } \\
\text { Nototheniidae }\end{array}$ & 4 & 10.5 & 4 & 23.5 & 1945 & 22.1 & 84.5 & $500^{\mathrm{a}}$ \\
\hline & \multicolumn{7}{|c|}{ Channichthyidae } & \\
\hline $\begin{array}{l}\text { Champsocephalus gunnari } \\
\text { Pseudochaenichthys }\end{array}$ & 1 & 2.6 & 2 & 11.8 & 724 & 8.4 & $367.8(348.4-400.1)$ & $357.6(294.2-467.9)$ \\
\hline georgianus & 4 & 10.5 & 4 & 23.5 & 3634 & 41.2 & $491.6(457.1-534.4)$ & $1244.8(940.8-1645.5)$ \\
\hline $\begin{array}{l}\text { Gempylidae } \\
\text { Paradiplospinus gracilis }\end{array}$ & 1 & 2.6 & 1 & 5.9 & 72 & 0.8 & & \\
\hline \multicolumn{9}{|l|}{ Macaroni penguin } \\
\hline \multicolumn{9}{|l|}{ Amphipods } \\
\hline Hyperid sp. & 2 & 5.0 & & & & & & \\
\hline Themisto gaudichaudii & 36 & 90.0 & & & 7429 & 67.3 & & \\
\hline Euphausids & & & & & & & & \\
\hline Euphausia superba & 2 & 5.0 & & & 1448 & 13.1 & $41.9(16.1-57.4)$ & \\
\hline E. frigida & 2 & 5.0 & & & & & & \\
\hline Thysanoessa sp. & 3 & 7.5 & & & 392 & 3.6 & & \\
\hline Decapods & & & & & & & & \\
\hline Chorismus antarcticus & 1 & 2.5 & & & & & & \\
\hline $\begin{array}{l}\text { Cephalopods } \\
\text { Onychoteuthidae }\end{array}$ & 8 & 20.0 & & & 113 & 1.0 & & \\
\hline Kondakovia longimana & 6 & 150 & 9 & 40.9 & 2 & $<0.1$ & $69.7(5.3-138.0)$ & $2.8(0.0-10.2)$ \\
\hline Omnastrephidae & & & & & & & & \\
\hline Martialia hyadesi & 2 & 5.0 & 10 & 45.9 & 110 & 1.0 & $198.1(160.9-264.1)$ & $135.7(44.4-339.2)$ \\
\hline $\begin{array}{l}\text { Brachioteuthidae } \\
\text { Brachioteuthis picta }\end{array}$ & 3 & 7.5 & 3 & 13.6 & 1 & $<01$ & $593(54.4-6751$ & $60109-491$ \\
\hline $\begin{array}{l}\text { Fish } \\
\text { Myctophidae }\end{array}$ & 19 & 47.5 & & & 1653 & 15.0 & & \\
\hline Electrona antarctica & 1 & 2.5 & 2 & 4.2 & 127 & 1.1 & 84.5 & 4.0 \\
\hline Krefftichthys anderssoni & 5 & 12.5 & 40 & 83.3 & 706 & 6.4 & $64.9(46.8-72.3)$ & $1.1(0.4-1.5)$ \\
\hline Protomyctophum choriodon & 1 & 2.5 & 1 & 2.1 & 162 & 1.5 & 85.2 & 5.1 \\
\hline Lampanyctus achirus & 1 & 2.5 & 1 & 2.1 & & & & \\
\hline Nototheniidae & & & & & & & & \\
\hline $\begin{array}{l}\text { Lepidonotothen larseni agg. } \\
\text { Channichthyidae }\end{array}$ & 1 & 2.5 & 1. & 2.1 & 86 & 0.8 & 67.8 & 2.7 \\
\hline $\begin{array}{l}\text { Champsocephalus gunnari } \\
\text { Pseudochaenichthys }\end{array}$ & 1 & 2.5 & 1 & 2.1 & 98 & 0.9 & 89.4 & 3.1 \\
\hline georgianus & 2 & 10.5 & 2 & 4.2 & 474 & 4.3 & 175.8 & 1.5 .0 \\
\hline
\end{tabular}


Appendix 1 (continued)

\begin{tabular}{|c|c|c|c|c|c|c|c|c|}
\hline \multirow{2}{*}{$\begin{array}{l}\text { Predator } \\
\text { Prey taxon }\end{array}$} & \multicolumn{2}{|c|}{ Occurrence } & \multicolumn{2}{|c|}{ Number } & \multicolumn{2}{|c|}{ Mass } & \multirow{2}{*}{$\begin{array}{l}\text { Total length }(\mathrm{mm}) \\
\text { mean (range) }\end{array}$} & \multirow{2}{*}{$\begin{array}{c}\text { Mass (g) } \\
\text { mean (range) }\end{array}$} \\
\hline & f & $\%$ & n & $\%$ & g & $\%$ & & \\
\hline \multicolumn{9}{|l|}{ Gentoo penguin } \\
\hline $\begin{array}{l}\text { Crustaceans } \\
\text { Amphipods }\end{array}$ & 24 & 92.3 & & & 274 & 12.9 & & \\
\hline Themisto gaudichaudii & 18 & 69.2 & & & 77 & 3.6 & & \\
\hline Euphausids & & & & & & & & \\
\hline $\begin{array}{l}\text { Euphausia superba } \\
\text { Mysids }\end{array}$ & 13 & 50.0 & & & 191 & 9.0 & $41.0(29.9-57.7)$ & \\
\hline Antarctomysis maxima & 2 & 7.7 & & & 6 & 0.3 & & \\
\hline $\begin{array}{l}\text { Cephalopods } \\
\text { Brachioteuthidae }\end{array}$ & 3 & 7.5 & & & 26 & 1.2 & & \\
\hline Brachioteuthis picta & 3 & 7.5 & 3 & 13.6 & 26 & 1.2 & $59.3(54.4-67.5)$ & $6.0(0.9-4.9)$ \\
\hline $\begin{array}{l}\text { Fish } \\
\text { Myctophidae }\end{array}$ & 25 & 96.1 & & & 1823 & 85.9 & & \\
\hline Electrona antarctica & 1 & 3.8 & 1 & 2.4 & 1 & 0.1 & 84.5 & 4.0 \\
\hline Protomyctophum choriodon & 2 & 7.7 & 2 & 4.8 & 5 & 0.2 & 85.2 & 5.1 \\
\hline $\begin{array}{l}\text { Nototheniidae } \\
\text { Lepidonotothen larseni agg. } \\
\text { Harpagiferidae }\end{array}$ & 1 & 2.51 & 2.4 & 15 & 0.7 & & $106.3(102.9-109.6)$ & 11.6 \\
\hline Champsocephalus gunnari & 11 & 42.3 & 35 & 85.3 & 1708 & 80.5 & $220.6(89.4-295.0)$ & $80.3(3.0-168.6)$ \\
\hline $\begin{array}{l}\text { Parachaenichthys } \\
\text { georgianus }\end{array}$ & 1 & 3.8 & 1 & 2.4 & 94 & 4.4 & 272.0 & 155.0 \\
\hline Antarctic prion & & & & & & & & \\
\hline Crustaceans & 33 & 100.0 & & & 404 & 97.6 & & \\
\hline Copepods & 30 & 90.9 & & & 330 & 79.7 & & \\
\hline Calanus acutus & 27 & 81.8 & & & 52 & 12.6 & & \\
\hline Calanoides simillimus & 17 & 42.4 & & & 17 & 4.1 & & \\
\hline Calanoides propinquus & 24 & 72.7 & & & 2 & 0.5 & & \\
\hline Rhincalanus gigas & 30 & 90.9 & & & 257 & 62.1 & & \\
\hline Drepanopus sp. & 13 & 39.3 & & & 1 & 0.2 & & \\
\hline Metridia sp. & 13 & 39.3 & & & 1 & 0.2 & & \\
\hline Caudacia sp. & 3 & 9.0 & & & & & & \\
\hline Amphipods & & & & & & & & \\
\hline Themisto gaudichaudii & 17 & 51.5 & & & 66 & 15.9 & & \\
\hline Euphausids & 21 & 63.6 & & & & & & \\
\hline Euphausia superba & 4 & 12.2 & & & 4 & 1.0 & & \\
\hline Decapods & & & & & & & & \\
\hline Pasiphaeasp. & 1 & 3.0 & & & 4 & 1.0 & & \\
\hline Cephalopods & 2 & 6.0 & & & 2 & 0.5 & & \\
\hline $\begin{array}{l}\text { Fish } \\
\text { Myctophidae }\end{array}$ & 5 & 15.2 & & & 8 & 1.9 & & \\
\hline Protomyctophum choriodon & 1 & 3.0 & 1 & & 8 & 1.9 & $75.0(65.1-91.2)$ & $3.0(2.0-4.9)$ \\
\hline
\end{tabular}

\section{LITERATURE CITED}

Ainley DG, Sydeman WJ, Norton J (1995) Upper trophic level predators indicate interannual negative and positive anomalies in the Californian Current food web. Mar Ecol Prog Ser 118:69-79

Anderson DW, Gress G, Mais KF (1982) Brown pelicans: influence of food suppply on reproduction. Oikos 39:23-31

Boyd IL, Arnould JPY, Barton T, Croxall JP (1994) Foraging behaviour of Antarctic fur seals during periods of contrasting prey abundance. J Anim Ecol 63:703-713

Boyd IL, Croxall JP, Lunn NJ, Reid K (1995) Population demography of Antarctic fur seals: the cost of reproduction and implications for life-histories. J Anim Ecol 64 : $505-518$
Boyd IL, McCafferty DJ, Reid K, Taylor R, Walker TR (1998) Dispersion of male and female Antarctic fur seals Arctocephalus gazella. Can J Fish Aquat Sci 55:845-852

Brierley AS, Watkins JL (1996) Acoustic targets at South Georgia and the South Orkney Islands during a season of krill scarcity. Mar Ecol Prog Ser 138:51-61

Brierley AS, Watkins JL, Murray AWA (1997) Interannual variability in krill abundance at South Georgia. Mar Ecol Prog Ser 150:87-98

Brierley AS, Watkins JL, Goss C, Wilkinson MT, Everson I (1998) Acoustic estimates of krill abundance at South Georgia, 1981-1998. Commission for the Conservation of Antarctic Marine Living Resources (CCAMLR), Hobart, Australia, WS-Area 48-98/9

Burger A.E, Piatt JF (1990) Flexible time budgets in common 
murres: buffers against variable prey abundance. Stud Avian Biol 14:71-83

Butterworth DS, Thomson RB (1995) Possible effect of different levels of krill fishing on predators - some initial modelling attempts. CCAMLR Science 2:79-88

Cairns DK (1987) Seabirds as indicators of marine food supplies. Biol Oceanogr 5:261-271

CCAMLR (Commission for the Conservation of Antarctic Marine Living Resources) (1995) CEMP Standard Methods. Hobart, CCAMLR, Australia

Clarke MR (1986) A handbook for the identification of cephalopod beaks. Clarendon Press, Oxford

Croxall JP (1984) Seabirds. In: Laws RM (ed) Antarctic ecology. Academic Press, London, p 522-619

Croxall JP, Prince PA (1979) Antarctic seabird and seal monitoring studies. Polar Rec 19:573-595

Croxall JP. Prince PA (1980) Food, feeding ecology and ecological segregation of seabirds at South Georgia. Biol J Linn Soc 14(1):103-131

Croxall JP, Rothery P (1995) Population change in the gentoo penguin Pygoscelis papua at Bird Island, South Georgia: potential roles of adult survival, recruitment and deferred breeding. In: Dann P, Norman I, Reilly P (eds) Penguins: advances in research and management. Surrey Beatty and Sons, Chipping Norton, Australia, p 26-38

Croxall JP, McCann TS, Prince PA, Rothery P (1988) Reproductive performance of seabirds and seals at South Georgia and Signy Island, South Orkney Islands, 1976-1987: implications for Southern Ocean monitoring studies. In: Sahrhage D (ed) Antarctic Ocean and resources variability. Springer-Verlag, Berlin, p 261-285

Croxall JP, Ricketts C, Prince PA (1984) Impact of seabirds on marine resources, especially krill, of South Georgia waters. In: Whittow GC, Rahn H (eds) Seabird energetics Plenum Publishing Corporation, New York, p 285-318

Croxall JP, Prince PA, Reid K (1997) Dietary segregation of krill-eating South Georgia seabirds. J Zool (Lond) 242 : 531-556

Croxall JP, Prince PA, Rothery P, Wood AG (1998) Population changes in albatrosses at South Georgia. In: Robertson G, Gales R (eds) Albatross biology and conservation. Surrey Beatty and Sons, Chipping Norton, Australia, p 98-83

Diamond, AW (1983) Feeding overlap in some tropical and temperate seabird communities. Stud Avian Biol 8:24-46

Furness RW, Ainley DG (1984) Threats to seabird populations presented by commercial fisheries. In: Croxall JP, Evans PGH, Schreiber RW (eds) Status and conservation of the world's seabirds. ICPB, Cambridge, p 701-708

Furness RW, Barrett, RT (1991) Ecological responses of seabirds to reductions in fish stocks in north Norway and Shetland. Acta 20th Congr Int Ornithol, Vol 4, p 2241-2245

Furness RW, Greenwood JJD (1993) Birds as monitors of environmental change. Chapman and Hall, London

Hamer KC, Monaghan P, Uttley JD, Walton P, Burns MD (1993) The influence of food supply on the breeding ecology of kittiwakes Rissa tridactyla in Shetland. Ibis 135: $255-263$

Hecht T (1987) A guide to the otoliths of Southern Ocean fishes. S Afr J Antarct Res 17:1-87

Hill HJ (1990) A new method for the measurement of Antarctic krill Euphausia superba Dana from predator food samples. Polar Biol 10:317-320

Hill HJ, Trathan PN, Croxall JP, Watkins JL (1996) A comparison of Antarctic krill Euphausia superba caught in nets and taken by macaroni penguins Eudyptes chrysolophus: evidence for selection? Mar Ecol Prog Ser 140:1-11

Hunt GL Jr, Priddle J, Whitehouse MJ, Veit RR, Heywood RB
(1992) Changes in seabird species abundance near South Georgia during a period of rapid change in sea surface temperature. Antarct Sci 4:15-22

Liddle GM (1994) Interannual variation in the breeding biology of the Antarctic prion Pachyptila desolata at Bird Island, South Georgia. J Zool (Lond) 234:125-139

Lunn NJ, Boyd IL, Croxall JP (1994) Reproductive performance of female Antarctic fur seals: the influence of age, breeding experience, environmental variation and individual quality. J Anim Ecol 63:827-840

Makarov RR, Denys GJ (1986) Stages of sexual maturity of Euphausia superba Dana. Scientific Committee for Antarctic Research, Cambridge

Monaghan P (1996) Relevance of the behaviour of seabirds to the conservation of marine environments. Oikos 77 : $227-237$

Monaghan P, Uttley JD, Burns MD, Thaine C, Blackwood J (1989) The relationship between food supply, reproductive effort and breeding success in arctic terns Sterna paradisaea. J Anim Ecol 58:261-274

Monaghan P, Walton P, Wanless S, Uttley JD, Burns MD (1994) Effects of prey abundance on the foraging behaviour, diving efficiency and time allocation of breeding guillemots Uria aalge. Ibis 136:214-222

Montevecchi WA, Berruti A (1991) Avian indication of pelagic fisheries and trophic changes in the southwest and northwest Atlantic. Acta 20th Congr Int Ornithol, Vol 4 , p 2246-2256

Montevecchi WA, Birt VL, Cairns DK (1988) Dietary changes of seabirds associated with local fisheries failures. Biol Oceanogr 5:153-161

Pennycuick CJ, Croxall JP, Prince PA (1984) Scaling of foraging radius and growth rate in petrels and albatrosses (Procellariiformes). Ornis Scand 15:145-154

Pierotti R, Annett CA (1990) Diet and reproductive output in seabirds. BioScience 40:568-574

Priddle J, Croxall JP, Everson I, Heywood RB, Murphy EJ, Prince PA, Sear CB (1988) Large-scale fluctuations in distribution and abundance of krill - a discussion of possible causes. In: Sahrhage D (ed) Antarctic Ocean and resources variability. Springer-Verlag, Berlin, p 169--182

Prince PA (1980a) The food and feeding ecology of blue petrel Halobaena caerulea and dove prion Pachyptila desolata. J Zool (Lond) 190:59-76

Prince PA (1980b) The food and feeding ecology of the greyheaded albatross Diomedea chrysostoma and blackbrowed albatross $D$. melanophris. Ibis 122:476-488

Prince PA, Ricketts C (1980) Relationships between food supply and growth in albatrosses: an interspecies chick fostering experiment. Ornis Scand 12:207-210

Prince PA, Rothery P, Croxall JP, Wood AG (1994) Population dynamics of black-browed and grey-headed albatrosses Diomedea melanophris and D. chrysostoma at Bird Island, South Georgia. Ibis 136:50-71

Prince PA, Croxall JP, Trathan PN, Wood AG (1998) The pelagic distribution of South Georgia albatrosses and their relationships with fisheries. In: Robertson G, Gales R (eds) Albatross biology and conservation. Surrey Beatty and Sons, Chipping Norton, Australia, p 137-167

Regehr HM, Montevecchi WA (1997) Interactive effects of food shortage and predation on breeding failure of blacklegged kittiwakes: indirect effects of fisheries activities and implications for indicator species. Mar Ecol Prog Ser $155: 249-260$

Reid K (1996) A guide to the use of otoliths in the study of predators at South Georgia. British Antarctic Survey, Cambridge 
Reid K, Arnould JPY (1996) The diet of Antarctic fur seals Arctocephalus gazella during the breeding season at South Georgia. Polar Biol 16:105-114

Reid K, Croxall JP, Prince PA (1996a) The fish diet of blackbrowed and grey-headed albatrosses Diomedea melanophris and D. chrysostoma at South Georgia. Polar Biol $16: 469-477$

Reid K, Trathan PN, Croxall JP, Hill HJ (1996b) Krill caught by predators and nets: differences between species and techniques. Mar Ecol Prog Ser 140:13-20

Reid K, Croxall JP, Edwards TM (1997) Interannual variation in the diet of the Antarctic prion Pachyptila desolata at South Georgia. Emu 97:126-132

Reid K, Liddle GM, Prince PA, Croxall JP (1999) Measurement of chick provisioning in Antarctic prions Pachyptila desolata using an automated weighing system. I Avian Biol 30:in press

Reid K, Watkins JL, Croxall JP, Murphy E (1999) Krill population dynamics at South Georgia 1991-1997, based on data from predators and nets. Mar Ecol Prog Ser 177:103-114

Reid K, Prince PA, Croxall JP (in press) Fly or die; the role of fat stores in the growth and development of grey-headed albatross chicks. Ibis

Sagar PM, Horning DS Jr (1998) Mass-related survival of fledging sooty shearwater Puffinus griseus at The Snares, New Zealand. Ibis 140:329-331

Shannon CE, Weaver W (1949) The mathematical theory of communication. University of Illinois Press, Urbana

Suddaby D, Ratcliffe N (1997) The effects of food availability on breeding Arctic terns Stema paradisaea. Auk 114: $524-530$

Editorial responsibility: Otto Kinne (Editor), Oldendorf/Luhe, Germany
Trathan PN, Croxall JP, Murphy EJ, Everson I (1998) Use of at-sea data to derive potential foraging ranges of macaroni penguins during the breeding season. Mar Ecol Prog Ser 169:263-275

Uttley JD, Walton P, Monaghan P, Austin G (1994) The effects of food abundance on breeding performance and adult time budgets of guillemots Uria aalge. Ibis 136:205- 213

Veit RR, Silverman ED, Everson I (1993) Aggregation patterns of pelagic predators and their principal prey, Antarctic krill, near South Georgia. J Anim Ecol 62:551-564

Williams R, McEldowney A (1990) A guide to the fish otoliths from waters off the Australian Antarctic Territory, Heard and Macquarie Island. ANARE (Aust Natl Antarct Res Exped) Res Notes 75

Williams TD (1991) Foraging ecology and diet of gentoo penguin Pygoscelis papua at South Georgia during winter and an assessment of their winter prey consumption. Ibis 133:3-13

Williams TD, Rothery P (1990) Factors affecting variation in foraging and activity patterns of gentoo penguins Pygoscelis papua during the breeding season at Bird Island, South Georgia. J Appl Ecol 27:1042-1054

Williams TD, Briggs DR, Croxall JP, Naito Y, Kato A (1992a) Diving pattern and performance in relation to foraging ecology in the gentoo penguin Pygoscelis papua. J Zool (Lond) 227:211-230

Williams TD, Kato A, Croxall JP, Naito Y, Briggs DR, Rodwell $S$, Barton TR (1992b) Diving pattern and performance in non-breeding gentoo penguins Pygoscelis papua during winter. Auk 109:223-234

Wilson RP (1984) An improved stomach pump for penguins and other seabirds. J Field Ornithol 55:109-112

Submitted: July 13, 1998; Accepted: October 8, 1998

Proofs received from author(s): January 28, 1999 